УДК 616-092

\title{
РОЛЬ ЦЕНТРАЛЬНОЇ НАУКОВО-ДОСЛІДНОЇ ЛАБОРАТОРІЇ У ПОКРАЩАННІ НАВЧАЛЬНО-МЕТОДИЧНОЇ РОБОТИ КАФЕДРИ ПАТОЛОГІЧНОї ФІЗІОЛОГІї
}

\author{
Ю. Є. Роговий, Л. О. Філіпова, В. А. Дорошко, М. В. Дікал, \\ К. В. Слободян, О. М. Лсньков
}

Буковинський держсавний медичний університет

\section{THE ROLE OF THE CENTRAL RESEARCH LABORATORY IN IMPROVING THE EDUCATIONAL AND METHODOLOGICAL WORK OF THE PATHOLOGICAL PHYSIOLOGY DEPARTMENT}

\author{
Yu. Ye. Rohovyi, L. O. Filipova, V. A. Doroshko, M. V. Dikal, \\ K. V. Slobodyan, O. M. Lienkov \\ Bukovynian State Medical University
}

\begin{abstract}
У представленій публікації обгрунтовано, що патологічна фізіологія як фундамент експериментальної медицини повинна відігравати провідну роль у формуванні у студентів основ клінічного мислення та виконувати функцію методології клінічних дисциплін, що досягасться шляхом постійної інтеграції наукової роботи центральної науково-дослідної лабораторії з навчально-методичною роботою кафедри патологічної фізіології.
\end{abstract}

In the present publication it is stated that the pathological physiology as the foundation of experimental medicine should play a leading role in forming the basis of students' clinical thinking and serve as methodology for clinical disciplines, which is achieved through permanent integration of the central research laboratory investigations with teaching and methodical work of the pathological physiology department.

Вступ. Головна мета навчально-методичної роботи медичного університету полягає у підготовці спеціалістів, здатних в умовах практичної охорони здоров'я клінічно мислити, оперативно приймати рішення як у типових, так і в нестандартних ситуаціях [3, 7]. Для досягнення поставленої мети рівень підготовки фахівців у галузі медицини повинен характеризуватися динамікою переходу з першого (“знаю”) та другого (“"знаю як”) рівнів піраміди Джорджа Міллера до третього (“демонструю”), а інколи навіть четвертого (“роблю") рівнів $[1,4]$. Для досягнення поставленої мети важливим моментом $€$ відкриття центральної науково-дослідноїлабораторії на базі кафедри патологічної фізіології.

Мета даної публікації полягала в обгрунтуванні відкриття центральної науково-дослідної лабораторії у покращанні навчально-методичної роботи кафедри патологічної фізіології.

Основна частина. Відомо, що основний метод патофізіології-проведення експериментів на тваринах [6]. Це принципово відрізняє патофізіологію від клінічних дисциплін. Основний девіз клініциста “Ідіть ближче до ліжка хворого" дає можливість лікарю набувати професійних навиків, правильно встановлювати діагноз, проводити ефективне лікування. Водночас при роботі з хворим лікар працює виключно в інтересах пацієнта, керуючись правилом Цельса "Primum non nocere".

Провідні інтереси патофізіолога полягають в іншому, а саме в пізнанні глибоких загальних закономірностей розвитку хвороби. 3 цією метою патофізіологи закликають науковців-медиків "Ідіть далі від ліжка хворого”, а саме в лабораторію, де ви будете проводити експерименти на тваринах з метою глибокого, фундаментального пізнання механізмів розвитку того чи іншого захворювання.

Така організація навчального процесу можлива тільки за умов постійного проведення наукової роботи в центральній науково-дослідній лабораторії Буковинського державного медичного університету, яка працює в постійній інтеграції з кафедрою патологічної фізіології із забезпеченням виконання науково-дослідної роботи кафедри патологічної фізіології “"Патогенетичне лікування дисфункції проксимального

() Ю. Є. Роговий, Л. О. Філіпова, В. А. Дорошко та ін. 
відділу нефрона та синдрому втрати іонів натрію 3 сечею, попередження розладів клубочково-канальцевого, канальцево-канальцевого балансу та тубуло-гломерулярного зворотного зв' язку за умов впливу екологічно несприятливих чинників".

Центральна науково-дослідна лабораторія БДМУ створена $з$ метою покращання методичного забезпечення й підвищення ефективності наукових досліджень у галузі фундаментальної та клінічної медицини.

Пріоритетним напрямом роботи центральної науково-дослідної лабораторії є дослідження патофізіології нирок та водно-сольового обміну.

Відкриття центральної науково-дослідної лабораторії на базі кафедри патологічної фізіології цілком відповідає змісту декларації щодо ролі і місця патофізіології в біомедичній культурі [5], яка прийнята на 5-му Міжнародному конгресі патофізіологів (June 28 - July 1, 2006 Beijing, China), що дає можливість проводити дослідження $з$ дотриманням правил проведення робіт з використанням експериментальних тварин (1977 р.) та положень Конвенції Ради Європи про охорону хребетних тварин, що використовуються в експериментах та інших наукових цілях (від 18 березня 1986 року).

Пропонується новий підхід у проведенні практичної частини заняття, а саме патофізіологічного експерименту. Суть його полягає в тому, що на практичній частині заняття не проводиться визначення одного якогось біохімічного чи функціонального показника, а увага зосереджується на ключових моментах складного комплексного патофізіологічного

\section{Література}

1. Милерян В. Е. Методические основы подготовки и проведения учебных занятий в медицинских вузах (методическое пособие) / В. Е. Милерян. -Киев, 1997. - 64 с.

2. Досвід навчально-методичної роботи кафедри патологічної фізіології / Ю. Є. Роговий, В. Ф. Мислицький, Л. О. Філіпова [та ін.] // Медична освіта. - 2001. - № 3. - С. $38-40$.

3. Роговий Ю. Є. Роль альтернативних методів навчання при викладанні теоретичних та клінічних медичних дисциплін / Ю. С. Роговий, А. В. Бочаров, Р. М. Кобилянська // Медична освіта. - 2003. - № 1.-С. 22-24.

4. Роговий Ю. Є. Роль нового методу електроакупунктурної діагностики і контролю за лікуванням “ИМЕДИСTECT+” у поліпшенні викладання патологічної фізіології/ Ю. Є. Роговий, Л. Г. Архіпова // Медична освіта. - 2006. - експерименту. Це дає можливість запропонувати студентам значну кількість вихідних даних для знову ж таки напруження такої сфери людської свідомості, як мислення та інтелект, що необхідно для обгрунтованої постановки діагнозу та логічного висновку. Наприклад, при вивченні патологічної фізіології нирок, на кафедрі студентам пропонується 45 показників функціонального стану нирок, які розраховуються за допомогою програми на комп'ютері за умов норми та гострої ниркової недостатності - сулемової нефропатії. Крім того, щоб у студентів сформувалися відповідні практичні навики у визначенні цих показників функції нирок, вони беруть участь не повністю у проведенні цілісного патофізіологічного експерименту, а тільки в його ключових моментах, що зумовлено обмеженістю часу практичного заняття. Студенти мають можливість на даному практичному занятті провести методику водного навантаження, збору сечі, визначення концентрації креатиніну в плазмі крові та сечі, концентрації іонів натрію в сечі та плазмі крові [2].

Висновок. У представленій публікації головну увагу зосереджено на тому, що патологічна фізіологія як фундамент експериментальної медицини повинна відігравати провідну роль у формуванні в студентів основ клінічного мислення та виконувати функцію методології клінічних дисциплін, що досягається шляхом постійної інтеграції наукової роботи центральної науково-дослідної лабораторії Буковинського державного медичного університету з навчально-методичною роботою кафедри патологічної фізіології.

\section{№3. - C. 107-109.}

5. Роль V Міжнародного конгресу патофізіологів (ISP 2006) у поліпшенні викладання та засвоєння провідної теоретичної дисципліни / Ю. Є. Роговий, Л. О. Філіпова, Л. Г. Архіпова, І. Л. Муравйова // Медична освіта. - 2007. №4. - С. 22-24.

6. Кафедра патофізіології Буковинського державного медичного університету : історія, сучасний стан проблеми, перспективи розвитку / Ю. Є. Роговий, Л. О. Філіпова, В. А. Дорошко, М. Д. Перепелюк // Бук. мед. вісник. -2009. - T.13, № 1.-С. 157-160.

7. Rohovyy Yu. Ye. Essential pathophysiology for medical students / Yu. Ye. Rohovyi, L. O. Filipova, V. A. Doroshko // Навчально-методичний посібник. -Chernivsti : Misto, 2011. -296 p. (ГРИФ МОН України №1/11-7022 від 29.07.10). 